Volume 9. No. 3, March 2021

International Journal of Emerging Trends in Engineering Research

Available Online at http://www.warse.org/IJETER/static/pdf/file/ijeter02932021.pdf

https://doi.org/10.30534/ijeter/2021/02932021

\title{
Effectiveness of Mobile Game-based Education on Algorithm Thinking: Informatic Engineering Case
}

\author{
Wirawan Istiono ${ }^{1}$ \\ ${ }^{1}$ Universtitas Multimedia Nusantara, Indonesia, wirawan.istiono@umn.ac.id
}

\begin{abstract}
Informatic engineering is one of the majors that are in high demand by prospective new students in Indonesia, but most of the new students have not learned lessons about algorithms and programming yet, so there are so many unsatisfactory grades in algorithm and programming lessons. The application of mobile game-based education algorithm is to find out whether using the algorithm learning method applied in mobile game-based can be useful or help to understand for users who are just starting to learn algorithms and programming. The target users to test the benefits gained from this mobile-based game are high school students, first-semester students majoring in informatic engineering or all users interested in learning programming languages. The algorithm learning material in the mobile game-based used in this study learns about some essential functions of the algorithm, namely the sequence function, looping function and procedural function. For a proof-of-concept, we implemented this mobile game-based education algorithm in a game called "KeyBot", as a case study that we propose. The game "KeyBot" has been tested by a number of users, from the user survey, it was concluded that the method of making mobile game-based education on the algorithm thinking is going well enough.
\end{abstract}

Key words : Education games, basic algorithm, game-based, programming, mobile.

\section{INTRODUCTION}

Since the implementation of the 2013 curriculum in education in Indonesia, computer subjects or often referred to as ICT (Information and Communication Technology) subjects were removed from compulsory subjects, this has caused most high schools to no longer include computer learning (ICT) in the daily schedule the school [1]. Based on our observations, although in most ICT subjects schools no longer exist, however, at a higher level in University, informatic engineering majors that are highly related to ICT subjects, it is still in high demand by these high school graduates.

Based on our observations, several Indonesian universities indicate that most of the early level students in the Informatic Engineering department have no basic knowledge of algorithms or never learned algorithms or programming subjects because these new students had not gotten basic programming when they were in high school yet, so the students sometimes have a problems in the traditional teaching process, and most of students who do not have basic knowledge of the algorithm cannot graduate with a satisfactory grade. That's the reason to make us think to create a mobile game-based education on algorithm thinking that can introduce ways of working or steps of programming with methods that are more fun and easily accepted by most students.

The reason why the application is applied to mobile devices is because, there are so many mobile or smartphone users in this era, including young people or students [2]. Based on this, our hypothesis is that the application of applications on mobile devices can reach more users and make it easier for users to use this algorithmic educational game application. Besides the reason why learning algorithm applications are applied in a game-based form, it is because using games in teaching can increase the productivity of students [3][4], And besides that, the students can get benefit from different teaching methods, because by building interactive and engaging learning game models based on mobile, so that interactive and engaging learning is expected to develop soft-skills and behavioural competencies that affect interpersonal interactions [5][6].

The application idea of this algorithm games is to make sequential step games with the goal of achieving a target, but in the step have limited inputs that can be applied, because of that, sometimes it needs repetitive or procedural techniques to apply to achieve the goals with limited input. Our initial hypothesis by providing mobile game-based education training on the algorithm thinking will be able to increase the percentage understanding level to students who have never learn the concept of programming or algorithms.

After applying the application to informatic engineering students, we will take a survey from students who had participated in training using a mobile game-based application on the algorithm thinking and then we will analyse the data obtained, whether the learning method of mobile game-based education on the algorithm thinking is useful or have positive impact for students who had tried this application.

The application of new methods in teaching such as game-based can help motivate students to continue try and try 
to complete the level of the learning game, compared to traditional methods that make students more quickly bored and reluctant in repeating the lessons taught. It can be concluded that with the same learning material but with different methods that can motivate students, the written value, the value of a student can increase [7].

Through educational games, a person will be able to experiment, discover, and get to know the learning material that surrounds it easier, because the material resources contribute to their training in physical, social and emotional that can be felt directly, so cause of that, absorbing learning material with educational games is more better [8][9]. With the game education method, a person will learn through discoveries, experiments made with all the objects that he finds in his environment [10]. Through a game, a person will also acquire skills in a natural way, and as in research conducted by Soler, after three years everything a child has, will have a direct connection to the game, and if it continues, the user can give a better meaning to the world in which he grows [11].

Most mobile game-based studies for student learning focus on the benefits of teaching and learning in the school or campus environment, some studies show, the use of games in teaching and learning can have a positive effect on student learning [12], although this does not happen to all case, because the process of making and designing learning games is essential as an attribute for the development of good educational games [13].

A child sees the world as a game, and all his actions are understood as part of the game that the child enjoys, in his research Gassó, discusses the critical role that Froebel has in relation to the child, regarding it as a spontaneous activity that they need for their physical and cognitive development. To implement that, he explained a series of materials, which he called gifts, through which intellectual education of the senses was trained, especially touch. He also uses all kinds of materials that improve the quality of education, such as objects and furniture used by children when farming [14]. For Garcia, the game was like the practice of organized motoric activity, regardless of whether it was regulated or spontaneous. It can be said that the child is playing when he is awake, stopping this activity only when he is sleeping. Ruiz Garcia also commented on this issue, according to him, "With interactive media such a game, a child can learn how to control his body, explore the world around him, resolve his emotional problems, become a social creature and have a place in the community" (p. 102). Without playing, children can not remain as a child [15].

Based on previous studies, we can conclude to utilize the stage of development of a child by building learning and knowledge through game methodology with an attractive and good game design, so that it is hoped that through education the game will be able to facilitate assimilation and also internalize teaching..

\section{RESEARCH METHOD}

The development educational algorithm applications use Agile methodology, where the step of making this educational game is divided into section, such as system requirements, system design, implementation and verification. System requirements is fulfilled by using questioner, which is distributed to 50 respondents, where $90 \%$ respondents aged is between 17 to 21 years, and $10 \%$ respondents aged is above 21 , all respondent are student who just starting to go to college or just start learn in college, that we think is suitable to try games education algorithm that we had developed. The questionnaire have 7 questions, and the most respondent are male respondents, where there are $86 \%$ male respondents and $14 \%$ female respondents, and also we found smartphone types on their mobile devices as much as $94 \%$ of Android smartphones and $6 \%$ based on iPhones. Where respondents who use their smartphone as entertainment to play games one to three hours a day as much as $42 \%$, and three to four hours a day as much as $26 \%$ and more than five hours is $6 \%$. And from the questioner we get respondents preferred play game genre action $26 \%$, and $8 \%$ for puzzle genre, $16 \%$ for strategy genre, $30 \%$ for Role playing games genre, $4 \%$ for simulation genre, and $14 \%$ for other genre. From the questioner, and from the questioner we can get too that many respondents did not know the learning algorithm using the game method, which is $54 \%$. And from questioner answer, we also get the player more love 3-Dimensional games depending 2-Dimensional games, where the respondents who choose 3-Dimensional as much as $72 \%$ and 2-Dimensional as much as $28 \%$. Based on the percentage obtained for each answer option, it can be concluded that more respondents play games for entertainment. In this Algorithm educational game, the game will build with 3-dimensional concept, where users can learn how to computer's working or algorithm in the form of a puzzle or strategy game with a better view. This game can be played on smartphone devices with the Android operating system, and it is hoped that with this algorithmic educational game, players can more easily understand the algorithm and programming. We also compared pre-existing algorithmic learning educational games and found several types of games as written in Table 1.

Table 1: Pre-existing Algorithm Education Game

\begin{tabular}{|l|l|l|l|}
\hline Title & Lightbot & $\begin{array}{l}\text { Learn } \\
\text { Coding With } \\
\text { Roly }\end{array}$ & $\begin{array}{l}\text { Algorithm } \\
\text { city }\end{array}$ \\
\hline Graphic Type & 2D Isometric & 2D & 2D isometric \\
\hline Platform & Android, IOS & Web & Android \\
\hline \multirow{3}{*}{ Genre } & $\begin{array}{l}\text { Puzzle, } \\
\text { Strategy, } \\
\text { Education }\end{array}$ & $\begin{array}{l}\text { Puzzle, } \\
\text { Strategy, } \\
\text { Education }\end{array}$ & $\begin{array}{l}\text { Puzzle, } \\
\text { strategy, } \\
\text { education }\end{array}$ \\
\hline Age Rating & $>9$ years & $7-10$ years & All years \\
\hline Player & Single player & Single player & Single player \\
\hline
\end{tabular}


From the comparison of algorithmic educational games shown in Table 1, found several deficiencies that will be described below. In the game "Learn coding with roly" found deficiencies wherein the game does not have a concept of looping and procedural learning. In "Lightbot" games and "Algorithm city" games are perfect for educational games, but the game is built in 2-Dimensional form using isometric, because of that, we want to try to create or add new features and change the game concept from 2-Dimension to 3-Dimension, because of the survey results that we have done, that 3-Dimensional games are more desirable than 2-Dimensional games, so we hoped with the construction of 3-Dimensional education game algorithms in terms of game design, it will be able to attract more users [16].

In the research I had written before, making learning algorithms using 2-Dimensional near isometric projection, found weaknesses when making "depth" on the tile of the characters, in addition, it also found weakness, when making sprites for the character or environment, we need to draw a lot character and environment sprite to handle all 2-Dimensional corner. [17], so from that problems, we changed form, from $2 \mathrm{D}$ into $3 \mathrm{D}$ as an update in making maps and characters, so when we changed from 2D into 3D, the problem of "depth" can be directly resolved, although other problems are found, but with use of the 3-Dimensional method when create maps and characters, can accelerate the process of making applications, and in addition, we can get more attractive game design and better view for user.

In the game that we made, called "Keybot", where the main menu of the game can be seen in Figure 1, in this game, there are several choices of levels and sublevels that have function as dividers of learning difficulties, where the higher level and higher sublevel, the more difficult learning levels, such as, for iteration and procedural functions in algorithm learning there are on level 2 or level 3 in this games. The level and sublevel menu choices in this game can be seen in Figure 2 and Figure 3.

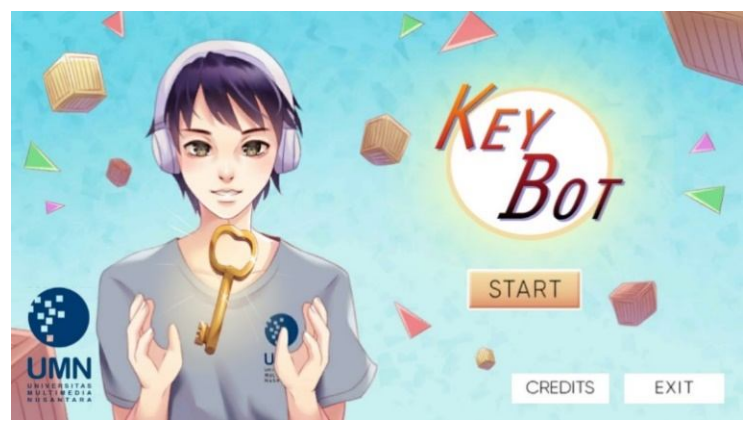

Figure 1: Main menu Keybot Games

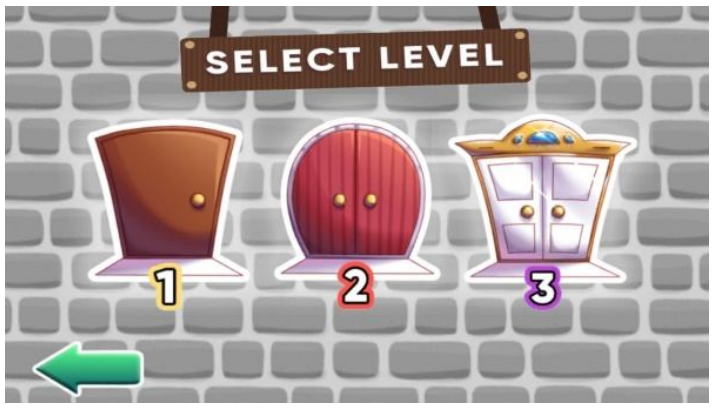

Figure 2: Level Menu Keybot Games

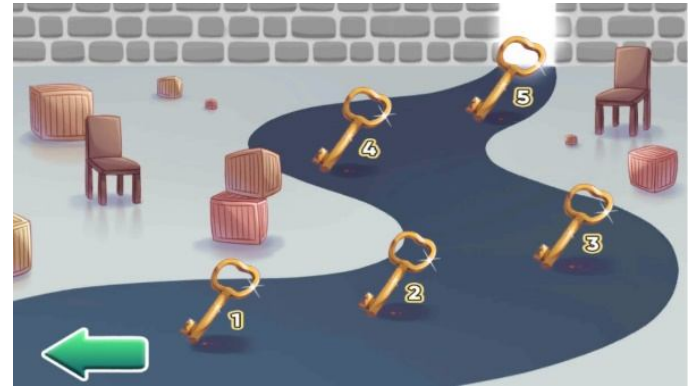

Figure 3: Sublevel menu Keybot Games

In the gameplay, the player will play a student named Hans who is trapped in a room, where he must get out of the room. But to get out through the door, the character must take a key first before opening the door. To move the character to get the key and exit the door, the player must input an appropriate instruction with a limited input slot, so the character can move correctly to get the key and exit through the door, in Figure 4 and Figure 5 below shown several levels of gameplay in the "Keybot" game. In the beginning level, instructions or how to play are provided for the user, so new players can understand the characters movement concept. Instructions or how to play panel before the game starts can be seen in Figure 6 below. Instructions or how to play panel will show at every level that has new conditions or new problems, such as new input that must be learned, or problems that can only be solved by looping and other problems.

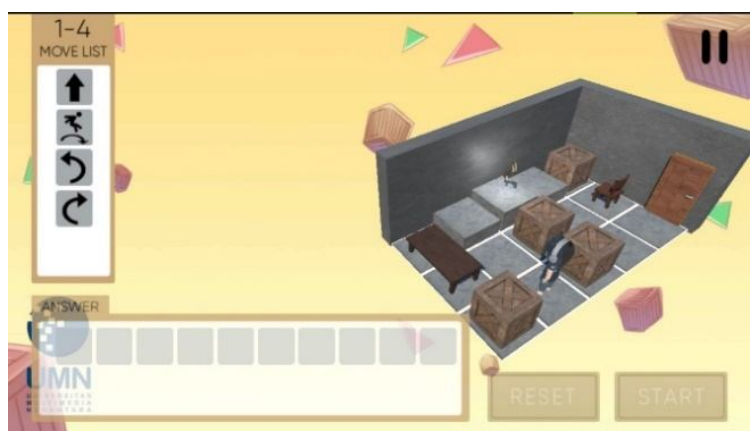

Figure 4: Gameplay Level Sequence Move Keybot Games 


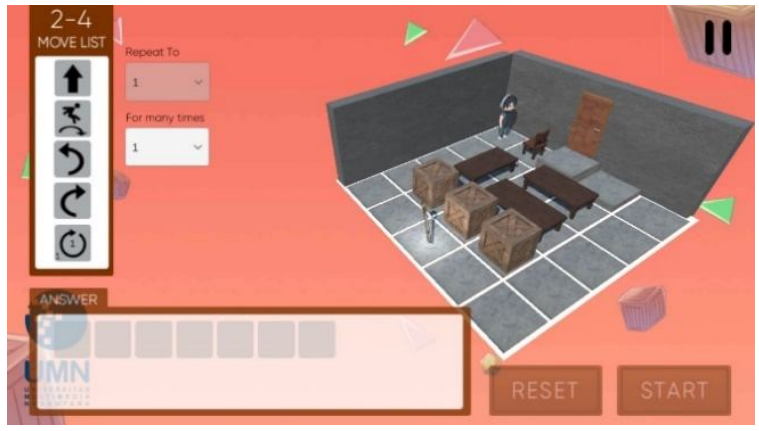

Figure 5: Gameplay Level need looping move

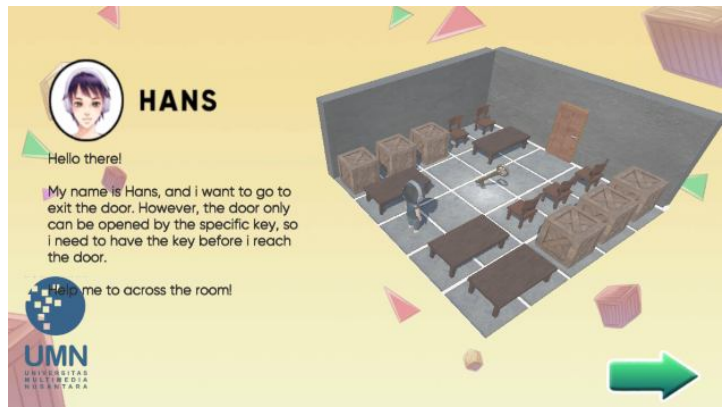

Figure 6: Instruction or tutorial in the beginning level

The sequence level, shown in Figure 4 is an example of a level that requires thinking about how to choose the right input step, so the character can get the key and open the lock. At Figure 5 is an example of a level that requires a looping process because if player using sequence steps, the player will not be able to complete the current level, therefore the player must use the correct input looping so that the level can be completed.

The following is an evaluation of the game application "Keybot", we do my best for consistency in designing game applications "Keybot" starting from the GUI (Graphical User Interface) where the transition from screen to screen must look consistent and not many changes, so it does not make users feel confused in the use of buttons and functions. And for the interface design is design for young people, we design like manga images with bright colours that make the game design better. In gameplay, the user interface design for the icon is also designed simple but easy to understand, so that when players play, it will be easy to understand the steps that must be input. At the design level, it is also divided into three levels, where the first level is the learning of algorithms with topic sequences and the second level is the discussion of looping, while the third level is the discussion of procedural and advanced looping, so our hope with order of levels is arranged in such a way, will make it easy for players to understand the steps of learning algorithms and programming. In the gameplay section "Keybot" also provided a pause menu or button, that menu functions for players can take a break while the gameplay is running, and when the pause button is pressed, the player can also choose to continue the game or return to the main menu. Every player completes a level, will show complete popup games, which use as a sign that the level is successfully completed, then the player can also continue to the next level or return to the main menu or repeat to same level..

\section{ReSUlt AND ANAlysis}

To find out the level of Effectiveness, a User Acceptance Test (UAT) is give to all players who had tried the game "Keybot", who is also an informatic engineering student, and the following below is a list of questions along with the results of the questionnaire from players, which can be seen on Table 2 below.

Table 2: Table Questioner using User Acceptance Test

\begin{tabular}{|c|c|c|c|c|c|c|}
\hline \multirow[t]{2}{*}{$\mathbf{Q}$} & \multirow[t]{2}{*}{ Question } & \multicolumn{5}{|c|}{ Percentage } \\
\hline & & $\mathbf{A}$ & B & $\mathbf{C}$ & D & $\mathbf{E}$ \\
\hline Q1 & $\begin{array}{l}\text { The "Keybot" algorithm } \\
\text { learning game has an } \\
\text { attractive user interface. }\end{array}$ & $10 \%$ & $53 \%$ & $25 \%$ & $11 \%$ & $0 \%$ \\
\hline Q2 & $\begin{array}{l}\text { By using the "Keybot" } \\
\text { algorithm learning game } \\
\text { application, it helps you in } \\
\text { understanding the sequence } \\
\text { process of the programming } \\
\text { algorithm }\end{array}$ & $38 \%$ & $49 \%$ & $10 \%$ & $1 \%$ & $2 \%$ \\
\hline Q3 & $\begin{array}{l}\text { By using the "Keybot" } \\
\text { algorithm learning game } \\
\text { application, helps me in } \\
\text { understanding the looping } \\
\text { process (repetition) in } \\
\text { programming }\end{array}$ & $24 \%$ & $44 \%$ & $22 \%$ & $7 \%$ & $3 \%$ \\
\hline Q4 & $\begin{array}{l}\text { By using the "Keybot" } \\
\text { algorithm learning game } \\
\text { application, helps me in } \\
\text { understanding procedural } \\
\text { processes in programming }\end{array}$ & $22 \%$ & $59 \%$ & $13 \%$ & $5 \%$ & $2 \%$ \\
\hline Q5 & $\begin{array}{l}\text { After using the Keybot } \\
\text { application, I became more } \\
\text { understanding the concept of } \\
\text { programming }\end{array}$ & $19 \%$ & $39 \%$ & $30 \%$ & $13 \%$ & $0 \%$ \\
\hline
\end{tabular}

From the survey results obtained from Table 2 where grade A means strongly agree, grade B means Agree, grade C means Neutral, grade D means Disagree and grade E means strongly disagree, and with using the Slovin technique, with an error margin of eight percent, then recapitulation can be made to obtain the final results of the questionnaire distributed to the players, as described in Table 3 below.

Table 3: User Acceptance Test Recapitulation

\begin{tabular}{|c|c|c|c|c|c|c|c|c|}
\hline \multirow[t]{2}{*}{$\mathbf{Q}$} & \multicolumn{5}{|c|}{ Score } & \multirow[t]{2}{*}{ Total } & \multirow{2}{*}{$\begin{array}{l}\text { Analysi } \\
\text { S (Total } \\
\text { / Rpd) }\end{array}$} & \multirow{2}{*}{$\begin{array}{l}\text { Percentag } \\
\text { e (Analyis } \\
\text { / Qn) } * 100\end{array}$} \\
\hline & 5 & 4 & 3 & 2 & 1 & & & \\
\hline $\begin{array}{l}\mathbf{Q} \\
\mathbf{1}\end{array}$ & 45 & $\begin{array}{c}18 \\
8 \\
\end{array}$ & 66 & 20 & 0 & 319 & 3,63 & 73 \\
\hline $\begin{array}{l}\mathbf{Q} \\
\mathbf{2}\end{array}$ & 165 & $\begin{array}{c}17 \\
2\end{array}$ & 27 & 2 & 2 & 368 & 4,18 & 84 \\
\hline $\begin{array}{l}\mathbf{Q} \\
\mathbf{3}\end{array}$ & 105 & $\begin{array}{c}15 \\
6\end{array}$ & 57 & 12 & 3 & 333 & 3,78 & 76 \\
\hline $\begin{array}{l}Q \\
4\end{array}$ & 95 & $\begin{array}{c}20 \\
8\end{array}$ & 33 & 8 & 2 & 346 & 3,93 & 79 \\
\hline $\begin{array}{l}\mathbf{Q} \\
\mathbf{5}\end{array}$ & 85 & $\begin{array}{c}13 \\
6\end{array}$ & 78 & 22 & 0 & 321 & 3,65 & 73 \\
\hline
\end{tabular}


Wirawan Istiono, International Journal of Emerging Trends in Engineering Research, 9(3), March 2021, 163 - 168

From Table 3 recapitulation above, so to get the average score is from calculate the total and divided by the number of questions, the total number is 1687 , and if divided by the number of questions, in this case is five, so can get the average is 76.68 , which agrees that by using a mobile game -based education on algorithm titled "Keybot" can help students to more easily understand algorithms and programming. While the general assessment results by Playstore user, dated December 10, 2019 who have played the game "Keybot", this game get an average star score of 4.1 from a total of 69 players who gave the score.

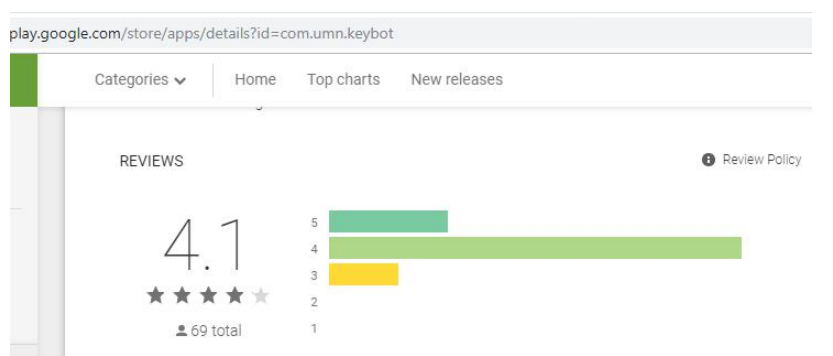

Figure 7. Keybot result rate from Playstore (source: https://play.google.com/store/apps/details?id=com.umn.keybot)

At that rate, for players who gave five stars there were eleven players, for four stars there were 50 players, while for three stars there were eight players, and there were no players who gave rates for two stars and one star. The results of the rate on the playstore, can be seen in Figure 7 above.

\section{CONCLUSION}

Based on the results of user acceptance test that had been carried out, found a score of 76.68 which agrees that an algorithmic learning application called "Keybot" can help players to be able to understand some programming material, such as sequence, looping and procedural as well as helping players who are at once Informatic engineering students to understand the concept of programming. While the general grade from the game players "Keybot" in the playstore, found a rate of 4.1, which can be concluded, the game "Keybot" is also acceptable to general players and gets a pretty good rate, although there are still some bugs and some entries and suggest from players, that might be able to apply to make this game more better and can give more good impact for many people.

\section{ACKNOWLEDGEMENT}

The author thank for Jansen and Cecilia for their cooperation during the "KeyBot" project, and thanks for Seng Hansun as my instructor and my friends for generously providing the game creation space.

\section{FUNDING STATEMENT}

This research and manuscript is funded and supported by Universitas Multimedia Nusantara, Tangerang, Indonesia.

\section{REFERENCES}

1. D. Rumahlatu, E. K. Huliselan, and J. Takaria, "An Analysis of the Readiness and Implementation of 2013 Curriculum in The West Part of Seram District, Maluku Province, Indonesia," vol. 11, no. 12, pp. 5662-5675, 2016.

2. M. W. B. Zhang and R. C. M. Ho, "Smartphone applications for immersive virtual reality therapy for internet addiction and internet gaming disorder," Technology and Health Care, vol. 25, no. 2, pp. 367-372, 2017.

3. S. Esper, S. R. Foster, and W. G. Griswold, "On the nature of fires and how to spark them when you're not there," SIGCSE 13: Proceeding of the 44th ACM technical symposium on Computer science education, $\mathrm{p}$. 305, 2013.

4. S. Trista and A. Rusli, "Historiar: Experience indonesian history through interactive game and augmented reality," Bulletin of Electrical Engineering and Informatics, vol. 9, no. 4, pp. 1518-1524, 2020.

5. R. E. Boyatzis, "Beyond competence: The choice to be a leader," Human Resource Management Review, vol. 3, no. 1, pp. 1-14, 1993.

6. M. K. K. Singh and N. A. Samah, "Impact of Smartphone: A Review on Positive and Negative Effects on Students," Asian Social Science, vol. 14, no. 11, p. 83, 2018.

7. G. Kiss and Z. Arki, "The Influence of Game-based Programming Education on the Algorithmic Thinking," Procedia - Social and Behavioral Sciences, vol. 237, no. June 2016, pp. 613-617, 2017.

8. F. M. M. Lucas, "The Game as an Early Childhood Learning Resource for Intercultural Education," Procedia - Social and Behavioral Sciences, vol. 237, no. June 2016, pp. 908-913, 2017.

9. F. M. M. Lucas, "The Game as an Early Childhood Learning Resource for Intercultural Education," Procedia - Social and Behavioral Sciences, vol. 237, no. June 2016, pp. 908-913, 2017.

10. J. Sampurna and W. Istiono, "Virtual Reality Game for Introducing Pencak Silat," International Journal of Interactive Mobile Technologies, vol. 15, no. 1, pp. 199-207, 2021.

11. F. M. Moreno Lucas, "Función pedagógica de los recursos materiales en educación infantil / Pedagogical function of material resources in early childhood education," Vivat Academia, vol. 0, no. 133, p. 12, 2015.

12. E. Z. F. Liu and P.-K. Chen, "The Effect of Game-Based Learning on Students' Learning Performance in Science Learning - A Case of 'Conveyance Go,"” Procedia - 
Wirawan Istiono, International Journal of Emerging Trends in Engineering Research, 9(3), March 2021, 163 - 168

Social and Behavioral Sciences, vol. 103, pp. 1044-1051, 2013.

13. K. A. Wilson et al., "Relationships between game attributes and learning outcomes: Review and research proposals," Simulation and Gaming, vol. 40, no. 2, pp. 217-266, 2009.

14. A. G. Gimeno, LA EDUCACION INFANTIL: METODOS, TECNICAS Y ORGANIZACION. Barcelona: Grupo Planeta (GBS), 2007.

15. F. J. García Castaño, A. Granados Martínez, and M. García-Cano Torrico, "De la educación multicultural e intercultural a la lengua y cultura de origen: reflexiones sobre el caso español," Boletín Informativo de Lenguas, vol. 7, no. 11, pp. 44-52, 1999.

16. G. H. \& X. Chen, "A comparison of usefulness of $2 \mathrm{D}$ and 3D representations of urban planning," Cartography and Geographic Information Science, vol. 42, no. 1, pp. 22-32, 2015.

17. W. Istiono, "Education Games To Learn Basic Algorithm With Near Isometric Projection Method," INTERNATIONAL JOURNAL OF ADVANCED STUDIES IN COMPUTER SCIENCE \& ENGINEERING, vol. 8, no. 7, pp. 6-10, 2019. 